\title{
Interactive Effect of NPK Fertilizers and Plant Densities on Growth and Yield of Pointed Gourd (Trichosanthes dioica Roxb.)
}

\author{
Sushree Choudhury* and Debasis Sarangi \\ Krishi Vigyan Kendra Ganjam-II, Odisha University of Agriculture and Technology, \\ Odisha, 7 51003, India \\ *Corresponding author
}

\begin{abstract}
A B S T R A C T
\section{Keywords}

Fertiliser levels, Plant density, Pointed gourd, Growth and Yield

Article Info

Accepted:

20 June 2020

Available Online:

10 July 2020

A field experiment consisting four levels of fertiliser and four levels plant densities in factorial RBD with three replications was conducted at at instructional farm of K.V.K, Ganjam-II, Berhampur, Odisha during 2017-18. Results revealed that different levels of fertiliser and plant densities significantly influenced growth and yield of pointed gourd. The results of present investigation indicated that application of 100 per cent recommended dose of NPK $(\mathrm{F} 2)$ and medium plant density $\left(\mathrm{S}_{3}\right)$ have maximum yield of pointed gourd. Interaction effect due to fertilizer combinations and plant densities on growth and yield parameters was found to be significant. Among the treatment combinations of $\mathrm{N}, \mathrm{P}, \mathrm{K}$ levels and plant densities, the treatment combination $\mathrm{T}_{11}\left(\mathrm{~F}_{3} \mathrm{~S}_{2}\right.$ : $125 \% \mathrm{RDF}+$ low plant density $(1.5 \mathrm{~m} \times 1.5 \mathrm{~m}))$ recorded maximum main vine length and number of branches per plant, however $\mathrm{T}_{8}\left(\mathrm{~F}_{2} \mathrm{~S}_{3}: 100 \% \mathrm{RDF}+\right.$ medium plant density $(1.5 \mathrm{~m}$ $\mathrm{x} 1.0 \mathrm{~m})$ ) recorded maximum number of nodes per vine, maximum weight of edible fruit, and total fruit yield per hectare.
\end{abstract}

\section{Introduction}

Pointed gourd (Trichosanthes dioica Roxb.) is an intensively cultivated cucurbitaceous vegetable in the eastern part of India, particularly in Odisha, Bengal, Assam, Bihar and some parts of Madhya Pradesh, Gujarat. It is an important remunerative perennial cucurbitaceous vegetable crop of Odisha and is known as the king of gourds and belongs to the family Cucurbitaceae. It is popularly known as parwal,, parmal, panal, patol and potala which is becoming more popular now a days.
It is one of the most nutritive and wholesome vegetable. It is easily digestible and is good for maintaining the healthy heart and brain. It is the highest dietary fibre $(3 \mathrm{~g} / 100 \mathrm{~g})$ containing vegetables. According to Seshadri (1990), 100g (fresh weight) of edible fruits contains $\mathrm{P}$ (40mg), Ca (30mg), Mg (9mg), Na (2.6mg), K (83mg), Cu (1.1mg), S (17mg), and $\mathrm{Cl}(4 \mathrm{mg})$ and also provides $20 \mathrm{kcal}$ energy. Every $100 \mathrm{~g}$ of fresh leaves contains $5.4 \mathrm{mg}$ proteins, $4.2 \mathrm{mg}$ fiber, $531 \mathrm{mg} \mathrm{Ca}$, and $73 \mathrm{mg} \mathrm{P}$ and also provides $55 \mathrm{kcal}$ energy. In the traditional Ayurvedic system of medicine, T. dioica fruits have been described to possess 
antihelminthic, antipyretic, diuretic, appetizing, digestive, expectorant, and antirheumatic effects. Seeds of T. dioica possess antibacterial as well as antifungal activities and are used in acid-dyspeptic disease treatment and roots have a strong purgative action, while the unripe fruits and tender shoots (typically consumed in curries) act as a laxative (Rahman et al., 2008). It is a perennial and dioecious vegetable that grows as vine with a pencil thickness stem. Roots are tuberous with long tap root system. Leaves are dark green, simple cordate, ovate and oblong. Flowers are tubular, white and fruits are oblong and smooth. Propagation of pointed gourd from seed is not desirable due to poor seed germination as well as dioecism which results in around 50\% unproductive male plants. Traditionally pointed gourd is multiplied through stem cuttings and root suckers. It has been observed that growers cultivate local cultivars and follow poor agrotechniques leading to low fruit yield. Lack of knowledge about the package of practices particularly on planting density and proper nutrient management are the prime reasons for lower yields.

Nutrient management is one of the key factors and its productivity is adversely affected, if the crop is not fed properly. Spacing is an important factor that will influence the plant population and affect the nutrient uptake of plants by creating competition between plants for nutrients, water and availability of light to the plants for synthesizing the food. By manipulation of inter and intra row spacing, several workers reported higher yields in other crops under field conditions (Singh et al., 2007), optimum nitrogen, phosphorus and potassium should be supplied to overcome the bottlenecks of production (Das et al., 1987).

Nitrogen fertilization favours the development of the aerial parts over roots and consequently the promotion of flowering and fruiting of many crops. Pointed gourd has huge vegetative growth which needs high amount of nitrogen (Hazra et al., 2011).Phosphorus plays an important role in energy transformation and metabolic process of plant and stimulates early root formation and growth, gives a rapid and vigorous growth to plants. Phosphorous is needed in the genetic coding material which controls cell division. Potassium is an important element in plant metabolism, promoting carbohydrate translocation from tops to roots. It plays a major role in the production of fruits. Hence, it is necessary for enhancing the fruit yield and yield attributes.

However, information on spacing, nitrogen, phosphorus and potassium requirements of pointed gourd is scarce under Indian conditions. So there is a need to standardize the optimum level of nitrogen, phosphorus potassium and plant densities for getting higher yields.

\section{Materials and Methods}

The present investigation was conducted at instructional farm of K.V.K, Ganjam-II, Berhampur, Odisha during 2017-18. Soil samples were collected from the experimental plot before planting the plants and application of manure and fertiliser from five randomly selected locations at a depth of $0-30 \mathrm{~cm}$ and composite sample was analysed for its physico- chemical properties and presented in Table 1.

\section{Treatment details}

This experiment was laid out in factorial RBD with 16 treatment combinations and 3 replications and the treatments comprised of two factors such as four levels of fertiliser and four levels plant densities and the details are given in Table2. 


\section{Fertiliser levels}

$\mathrm{F}_{1}: 75 \% \mathrm{RDF}$

$\mathrm{F}_{2}: 100 \% \mathrm{RDF}$

$\mathrm{F}_{3}: 125 \% \mathrm{RDF}$

$\mathrm{F}_{4}$ : Control

\section{Plant densities}

$\mathrm{S}_{0}: 1.0 \mathrm{~m} \times 0.5 \mathrm{~m}$ (very high plant density: 20,000 plants/ha)

$\mathrm{S}_{1}: 1.0 \mathrm{~m} \times 1.0 \mathrm{~m}$ (high plant density: 10,000 plants/ha)

$\mathrm{S}_{2}: 1.5 \mathrm{~m} \times 1.5 \mathrm{~m}$ (low plant density: 4444 plants/ha)

$\mathrm{S}_{3}: 1.5 \mathrm{~m} \times 1.0 \mathrm{~m}$ (medium plant density: 6666 plants/ha)

The experimental area was divided into plots of $5.0 \mathrm{~m} \mathrm{x} 4.0 \mathrm{~m}$ size. Irrigation channels of $1.0 \mathrm{~m}$ wide were provided for each row of plots. $30 \mathrm{~cm}^{3}$ pits were dug at a spacing of $1.0 \mathrm{~m} \times 0.5 \mathrm{~m}, 1.0 \mathrm{~m} \times 1.0 \mathrm{~m}, 1.5 \mathrm{~m} \times 1.5 \mathrm{~m}$ and $1.5 \mathrm{mx} 1.0 \mathrm{~m}$. in each plot. Well decomposed farmyard manure @ $5 \mathrm{~kg}$ per pit was incorporated by mixing with the soil uniformly as basal application and filled up to 3- $5 \mathrm{~cm}$ above the ground level. Rooted vine cuttings of $15-20 \mathrm{~cm}$ length, pencil thickness were planted. A space of 30 centimetres was uniformly left from the borders of the plot. The recommended dose of fertilizer for pointed gourd is $150 \mathrm{~kg}, 60 \mathrm{~kg}$ and $60 \mathrm{~kg} / \mathrm{ha}$ nitrogen, phosphorus and potash were applied respectively as $75 \% \mathrm{RDF}, 100 \% \mathrm{RDF}, 125 \%$ RDF, Control through urea ( $46 \% \mathrm{~N})$, single super phosphate $(16 \% \mathrm{P})$ and muriete of potash $(60 \% \mathrm{~K})$ as per treatment combination.

Biometric observations on growth and yield attributing parameters viz., main vine length $(\mathrm{m})$, number of branches per plant, number of nodes per vine, yield per vine $(\mathrm{kg})$, total yield (t ha-1) were recorded. The collected data were subjected to statistical analysis as per Sukhatme and Amble (1995).

\section{Results and Discussion}

\section{Effect of NPK fertilizers and plant densities on vegetative parameters of pointed gourd}

\section{Main vine length (m)}

The perusal of data presenting in table 3 shows that the effect of NPK had significant influence on the main vine length. The maximum main vine length $(6.98 \mathrm{~m})$ was observed in $\mathrm{F}_{3}$ (i.e. 125 per cent recommended dose of NPK) which was found to be significantly higher over $F_{2}$ and $F_{1}$, whereas, minimum main vine length $(3.13 \mathrm{~m})$ was recorded under $\mathrm{F}_{4}$ (control) treatment.

This might be due to the fact that the NPK are considered as one of the major nutrient required for proper growth and development of the plant. Nitrogen is a very important component of protoplasm and its favourable effect on chlorophyll content of leaves might have increased synthesis of carbohydrates, amino acids etc., from which the phytohormones such as auxins, gibberellins, cytokinins have been synthesized and phosphorus is a constituent of nucleic acid, phytin and phospholipids resulting increased plant height. Anjanappa et al., (2012), Arshad et al., (2014) in cucumber were also reported increased plant height with increase in fertilizer levels.

The effect of plant density on main vine length was found to be significant. Significantly maximum main vine length $(6.59 \mathrm{~m})$ was recorded with low plant density $\left(\mathrm{S}_{2}-1.5 \times 1.5 \mathrm{~m}\right)$, followed by main vine length $5.20 \mathrm{~m}$ ) with medium plant density $\left(\mathrm{S}_{3}-1.5 \times 1 \mathrm{~m}\right)$. However, the minimum main 
vine length $(3.27 \mathrm{~m})$ was recorded with very high plant density $\left(\mathrm{S}_{0}-1.0 \mathrm{~m} \times 0.5 \mathrm{~m}\right)$. This could be due to availability of more space, nutrients, water and less competition from the adjacent plants in wider planting when compared to closer spaced plants.

The interaction effect due to nutrient combinations and plant densities on main vine length was found to be significant. The treatment combination $\left(\mathrm{T}_{11}\right)-\mathrm{F}_{3} \mathrm{~S}_{2}$ produced maximum main vine length $(9.93 \mathrm{~m})$ which was followed by $\left(\mathrm{T}_{12}\right)-\mathrm{F}_{3} \mathrm{~S}_{3}(7.55 \mathrm{~m})$. However the treatment combination $\left(\mathrm{T}_{13}\right)-\mathrm{F}_{4} \mathrm{~S}_{0}$ recorded the minimum vine length $(2.67 \mathrm{~m})$. These results are in conformity with the findings of Jan et al., (2000) in bottle gourd and Dash and Tripathy (2001) in pointed gourd.

\section{Number of branches per plant}

It is seen from table 3 that the number of branches per plant significantly influenced by the different doses of NPK. Significantly highest (10.42) number of branches was recorded with $\mathrm{F}_{3}$ and lowest (3.98) was recorded with $\mathrm{F}_{4}$ (control). This might be due to the fact that increased NPK levels, helped in the expansion of leaf area and chlorophyll content which together might have accelerated the photosynthetic rates and in turn increased the supply of carbohydrates to plants resulting more number of branches per plant.

Significantly maximum number of branches (9.34) was recorded with low plant density $\left(\mathrm{S}_{2}-1.5 \times 1.5 \mathrm{~m}\right)$. However, the minimum number of branches (3.05) was recorded with very high plant density $\left(\mathrm{S}_{0}-1.0 \mathrm{~m} \times 0.5 \mathrm{~m}\right)$. This might be due to the fact that maximum utilization of space, water, nutrient and less competition from the adjacent plants in wider spaced plants.
The interaction effect due to nutrient combinations and plant densities on number of branches per plant was found to be significant. The treatment combination $\left(\mathrm{T}_{11}\right)$ $\mathrm{F}_{3} \mathrm{~S}_{2}$ produced maximum(12.45) number of branches per plant and $\left(T_{13}\right)-F_{4} S_{0}$ recorded the minimum (3.05). These results are in conformity with the findings of, Jan et al., (2000) in bottle gourd and Choudhari and More (2002) in cucumber.

\section{Number of nodes per vine}

Different fertilizer levels imparted significant difference in the number of nodes per vine. From the table 3 it is clear that the lowest number of nodes (39.53) was recorded in $\mathrm{F}_{4}$ (control), while the highest number of nodes (85.83) was associated with $F_{2}$ (i.e. 100 per cent recommended dose of NPK). This might be due to maximum utilization of nitrogen, phosphorus and potash from the soil and increase the synthesis of amino acid which act as precursor of polyamine and secondary messenger thus promote the development of nodes.

It was evident from the data that minimum number of nodes per vine (52.77) was recorded with $\mathrm{S}_{0}$ (very high plant density). In very high plant density due to narrow spacing there is more competition for nutrient, water, space, from the adjacent plants resulting in minimum number of nodes

Number of nodes per vine was significantly influenced by interaction of fertilizer levels and plant densities. The treatment combination $\left(\mathrm{T}_{8}\right) \mathrm{F}_{2} \mathrm{~S}_{3}$ produced maximum number of nodes per vine (103.33) and (T13)$\mathrm{F}_{4} \mathrm{~S}_{0}$ recorded the minimum (29.33) number of nodes per vine. These results are in conformity with the findings of, Jan et al., (2000) in bottle gourd and Choudhari and More (2002) in cucumber. 
Effect of NPK fertilizers and plant densities on Yield attributing parameters of pointed gourd

\section{Weight of the edible fruit (g)}

From the table 4 it is clear that the interaction pertaining to $\mathrm{N}, \mathrm{P}, \mathrm{K}$ levels and plant densities (Fig. 1a). recorded lower fruit weight $(18.05 \mathrm{~g})$ with $\left(\mathrm{T}_{13}\right)-\mathrm{F}_{4} \mathrm{~S}_{0}$. The higher weight of edible fruit $(23.55 \mathrm{~g})$ was recorded with $\left(\mathrm{T}_{8}\right)-\mathrm{F}_{2} \mathrm{~S}_{3}$, which might be due to availability of balanced amount of nutrients and higher rate of assimilation and ultimately more production of carbohydrates and their translocation to the storage organs like fruits. These results indicated that the efficiency of nitrogen increased considerably by a simultaneous application of phosphorus and potassium. Improvement of vegetative growth and fruiting could be due to combined application of nitrogen, phosphorus and potassium. Similar results were in conformity with the findings of Jan et al., (2000) in bottle gourd.

Table.1 Physio-chemical properties of experimental soil

\begin{tabular}{|l|l|}
\hline Soil Properties & Values \\
\hline Soil texture & Loamy sand \\
\hline Soil pH & 5.8 \\
\hline Electrical conductivity $(\mathbf{d S}$ m-1) & 0.07 \\
\hline Organic carbon $(\%)$ & 0.46 \\
\hline Available N $(\mathbf{k g}$ ha-1) & 207.2 \\
\hline Available P(kg ha-1) & 16.31 \\
\hline Available K (kg ha-1) & 172.6 \\
\hline Available S (kg ha-1) & 17.5 \\
\hline
\end{tabular}

Table.2 Combination of N, P, K levels and Plant density treatments

\begin{tabular}{|l|l|}
\hline $\begin{array}{l}\text { Treatment } \\
\text { Notation }\end{array}$ & $\begin{array}{l}\text { Combination of N,P,K levels and Plant } \\
\text { density }\end{array}$ \\
\hline $\mathbf{T}_{\mathbf{1}}$ & $\mathrm{F}_{1} \mathrm{~S}_{0}: 75 \% \mathrm{RDF}+1.0 \mathrm{~m} \times 0.5 \mathrm{~m}$ \\
\hline $\mathbf{T}_{\mathbf{2}}$ & $\mathrm{F}_{1} \mathrm{~S}_{1}: 75 \% \mathrm{RDF}+1.0 \mathrm{~m} \times 1.0 \mathrm{~m}$ \\
\hline $\mathbf{T}_{\mathbf{3}}$ & $\mathrm{F}_{1} \mathrm{~S}_{2}: 75 \% \mathrm{RDF}+1.5 \mathrm{~m} \times 1.5 \mathrm{~m}$ \\
\hline $\mathbf{T}_{\mathbf{4}}$ & $\mathrm{F}_{1} \mathrm{~S}_{3}: 75 \% \mathrm{RDF}+1.5 \mathrm{~m} \times 1.0 \mathrm{~m}$ \\
\hline $\mathbf{T}_{\mathbf{5}}$ & $\mathrm{F}_{2} \mathrm{~S}_{0}: 100 \% \mathrm{RDF}+1.0 \mathrm{~m} \times 0.5 \mathrm{~m}$ \\
\hline $\mathbf{T}_{\mathbf{6}}$ & $\mathrm{F}_{2} \mathrm{~S}_{1}: 100 \% \mathrm{RDF}+1.0 \mathrm{~m} \times 1.0 \mathrm{~m}$ \\
\hline $\mathbf{T}_{\mathbf{7}}$ & $\mathrm{F}_{2} \mathrm{~S}_{2}: 100 \% \mathrm{RDF}+1.5 \mathrm{~m} \times 1.5 \mathrm{~m}$ \\
\hline $\mathbf{T}_{\mathbf{8}}$ & $\mathrm{F}_{2} \mathrm{~S}_{3}: 100 \% \mathrm{RDF}+1.5 \mathrm{~m} \times 1.0 \mathrm{~m}$ \\
\hline $\mathbf{T}_{\mathbf{9}}$ & $\mathrm{F}_{3} \mathrm{~S}_{0}: 125 \% \mathrm{RDF}+1.0 \mathrm{~m} \times 0.5 \mathrm{~m}$ \\
\hline $\mathbf{T}_{\mathbf{1 0}}$ & $\mathrm{F}_{3} \mathrm{~S}_{1}: 125 \% \mathrm{RDF}+1.0 \mathrm{~m} \times 1.0 \mathrm{~m}$ \\
\hline $\mathbf{T}_{\mathbf{1 1}}$ & $\mathrm{F}_{3} \mathrm{~S}_{2}: 125 \% \mathrm{RDF}+1.5 \mathrm{~m} \times 1.5 \mathrm{~m}$ \\
\hline $\mathbf{T}_{\mathbf{1 2}}$ & $\mathrm{F}_{3} \mathrm{~S}_{3}: 125 \% \mathrm{RDF}+1.5 \mathrm{~m} \times 1.0 \mathrm{~m}$ \\
\hline $\mathbf{T}_{\mathbf{1 3}}$ & $\mathrm{F}_{4} \mathrm{~S}_{0}:$ Control $+1.0 \mathrm{~m} \times 0.5 \mathrm{~m}$ \\
\hline $\mathbf{T}_{\mathbf{1 4}}$ & $\mathrm{F}_{4} \mathrm{~S}_{1}:$ Control $+1.0 \mathrm{~m} \times 1.0 \mathrm{~m}$ \\
\hline $\mathbf{T}_{\mathbf{1 5}}$ & $\mathrm{F}_{4} \mathrm{~S}_{2}:$ Control $+1.5 \mathrm{~m} \times 1.5 \mathrm{~m}$ \\
\hline $\mathbf{T}_{\mathbf{1 6}}$ & $\mathrm{F}_{4} \mathrm{~S}_{3}:$ Control $+1.5 \mathrm{~m} \times 1.0 \mathrm{~m}$ \\
\hline
\end{tabular}


Table.3 Effect of NPK fertilizers and plant densities on vegetative parameters in pointed gourd (Trichosanthes dioica Roxb.)

\begin{tabular}{|c|c|c|c|c|c|c|c|c|c|c|c|c|c|c|c|}
\hline & \multicolumn{5}{|c|}{ Main vine length (m) } & \multicolumn{5}{|c|}{ Number of branches per plant } & \multicolumn{5}{|c|}{ Number of nodes per vine } \\
\hline & $\mathrm{S}_{0}$ & $\mathrm{~S}_{1}$ & $\mathrm{~S}_{2}$ & $\mathrm{~S}_{3}$ & Mean & $\mathrm{S}_{0}$ & $\mathrm{~S}_{1}$ & $\mathrm{~S}_{2}$ & $\mathrm{~S}_{3}$ & Mean & $\mathrm{S}_{0}$ & $\mathrm{~S}_{1}$ & $\mathrm{~S}_{2}$ & $\mathrm{~S}_{3}$ & Mean \\
\hline $\mathbf{F}_{1}$ & 3.13 & 4.64 & 5.91 & 4.95 & 4.66 & 3.25 & 5.35 & 9.7 & 6.63 & 6.23 & 45.79 & 58.66 & 72.5 & 68.76 & 61.43 \\
\hline $\mathbf{F}_{2}$ & 3.37 & 5.22 & 6.65 & 5.54 & 5.20 & 6.53 & 8.63 & 10.99 & 7.82 & 8.49 & 71.34 & 80.00 & 88.66 & 103.33 & 85.83 \\
\hline $\mathbf{F}_{3}$ & 3.89 & 6.53 & 9.93 & 7.55 & 6.98 & 7.54 & 9.77 & 12.45 & 11.93 & 10.42 & 64.62 & 75.66 & 87.00 & 96.00 & 80.82 \\
\hline $\mathbf{F}_{4}$ & 2.67 & 3.26 & 3.85 & 2.74 & 3.13 & 3.05 & 4.18 & 4.22 & 4.45 & 3.98 & 29.33 & 35.50 & 44.29 & 48.98 & 39.53 \\
\hline Mean & 3.27 & 4.91 & 6.59 & 5.20 & & 5.09 & 6.98 & 9.34 & 7.71 & & 52.77 & 62.46 & 73.11 & 79.27 & \\
\hline & $\mathrm{F}$ & $\mathrm{S}$ & FXS & & & $\mathrm{F}$ & $\mathrm{S}$ & FXS & & & $\mathrm{F}$ & $\mathrm{S}$ & FXS & & \\
\hline $\operatorname{SEm}( \pm)$ & 0.190 & 0.190 & 0.379 & & & 0.27 & 0.27 & 0.54 & & & 1.08 & 1.08 & 2.15 & & \\
\hline $\mathrm{CD}(0.05)$ & 0.548 & 0.548 & 1.096 & & & 0.77 & 0.77 & 1.55 & & & 3.11 & 3.11 & 6.22 & & \\
\hline
\end{tabular}

Table.4 Effect of NPK fertilizers and plant densities on yield attributing parameters in pointed gourd (Trichosanthes dioica Roxb)

\begin{tabular}{|c|c|c|c|c|c|c|c|c|c|c|c|c|c|c|c|}
\hline & \multicolumn{5}{|c|}{ Length of the edible fruit $(\mathrm{cm})$} & \multicolumn{5}{|c|}{ Fruit diameter (cm) } & \multicolumn{5}{|c|}{ Weight of the edible fruit (g) } \\
\hline & $\mathrm{S}_{0}$ & $\mathrm{~S}_{1}$ & $\mathrm{~S}_{2}$ & $\mathrm{~S}_{3}$ & Mean & $\mathrm{S}_{0}$ & $\mathrm{~S}_{1}$ & $\mathrm{~S}_{2}$ & $\mathrm{~S}_{3}$ & Mean & $\mathrm{S}_{0}$ & $\mathrm{~S}_{1}$ & $\mathrm{~S}_{2}$ & $\mathrm{~S}_{3}$ & Mean \\
\hline $\mathbf{F}_{1}$ & 3.78 & 4.05 & 4.94 & 6.22 & 4.75 & 3.33 & 3.62 & 3.87 & 3.99 & 3.70 & 19.56 & 21.29 & 22.08 & 22.27 & 21.30 \\
\hline $\mathbf{F}_{2}$ & 4.82 & 5.64 & 6.6 & 7.01 & 6.02 & 4.11 & 4.37 & 4.63 & 4.78 & 4.47 & 21.27 & 22.46 & 23.33 & 23.55 & 22.65 \\
\hline $\mathbf{F}_{3}$ & 4.13 & 4.95 & 5.91 & 6.32 & 5.33 & 3.60 & 3.72 & 3.87 & 4.13 & 3.83 & 19.32 & 21.44 & 22.76 & 23.34 & 21.72 \\
\hline $\mathbf{F}_{4}$ & 3.26 & 3.38 & 4.33 & 5.48 & 4.11 & 3.19 & 3.38 & 3.45 & 3.64 & 3.42 & 18.05 & 19.12 & 19.79 & 20.11 & 19.27 \\
\hline \multirow[t]{2}{*}{ Mean } & 4.00 & 4.51 & 5.45 & 6.26 & & 3.56 & 3.77 & 3.96 & 4.14 & & 19.55 & 21.08 & 21.99 & 22.32 & \\
\hline & $\mathrm{F}$ & S & FXS & & & $\mathrm{F}$ & $\mathrm{S}$ & FXS & & & $\mathrm{F}$ & S & FXS & & \\
\hline $\operatorname{SEm}( \pm)$ & 0.05 & 0.05 & 0.09 & & & 0.03 & 0.03 & 0.07 & & & 0.23 & 0.23 & 0.46 & & \\
\hline $\mathrm{CD}(0.05)$ & 0.14 & 0.14 & 0.27 & & & 0.10 & 0.10 & $\mathrm{NS}$ & & & 0.66 & 0.66 & $\mathrm{NS}$ & & \\
\hline
\end{tabular}


Table.5 Effect of NPK fertilizers and plant densities on yield parameters in pointed gourd (Trichosanthes dioica Roxb.)

\begin{tabular}{|l|c|c|c|c|c|c|c|c|c|c|}
\hline & \multicolumn{4}{|c|}{ Yield per vine (kg) } & \multicolumn{5}{c|}{ Total yield (t ha-1) } \\
\hline & $\mathrm{S}_{0}$ & $\mathrm{~S}_{1}$ & $\mathrm{~S}_{2}$ & $\mathrm{~S}_{3}$ & Mean & $\mathrm{S}_{0}$ & $\mathrm{~S}_{1}$ & $\mathrm{~S}_{2}$ & $\mathrm{~S}_{3}$ & Mean \\
\hline $\mathbf{F}_{\mathbf{1}}$ & 3.13 & 3.74 & 4.87 & 5.26 & 4.25 & 13.68 & 14.97 & 16.28 & 20.59 & 16.38 \\
\hline $\mathbf{F}_{\mathbf{2}}$ & 4.72 & 5.33 & 6.02 & 6.90 & 5.74 & 17.98 & 21.15 & 29.92 & 31.25 & 25.08 \\
\hline $\mathbf{F}_{\mathbf{3}}$ & 4.09 & 4.69 & 5.72 & 5.83 & 5.08 & 16.12 & 19.29 & 22.29 & 24.32 & 20.51 \\
\hline $\mathbf{F}_{\mathbf{4}}$ & 1.71 & 1.91 & 2.21 & 2.41 & 2.06 & 6.87 & 7.26 & 8.04 & 8.29 & 7.62 \\
\hline Mean & 3.41 & 3.92 & 4.71 & 5.10 & & 13.66 & 15.67 & 19.13 & 21.11 & \\
\hline & $\mathrm{F}$ & $\mathrm{S}$ & $\mathrm{FXS}$ & & & $\mathrm{F}$ & $\mathrm{S}$ & $\mathrm{FXS}$ & & \\
\hline $\mathbf{S E m}(\mathbf{\pm})$ & 0.11 & 0.11 & 0.22 & & & 0.79 & 0.79 & 1.57 & & \\
\hline $\mathbf{C D}(\mathbf{0 . 0 5})$ & 0.31 & 0.31 & 0.62 & & & 2.27 & 2.27 & 4.53 & & \\
\hline
\end{tabular}

Fig.1a Weight of edible fruit $(\mathrm{g})$

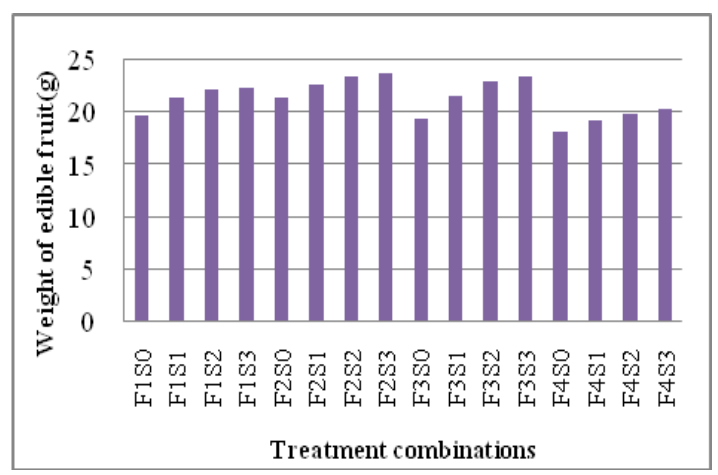

\section{Length of the edible fruit $(\mathrm{cm})$}

The effect of N,P,K fertilizer levels and plant densities recorded higher length of edible fruits with $\left(\mathrm{T}_{8}\right)-\mathrm{F}_{2} \mathrm{~S}_{3}(7.01 \mathrm{~cm})$ which was followed by $\left(\mathrm{T}_{12}\right)-\mathrm{F}_{3} \mathrm{~S}_{3}(6.32 \mathrm{~cm})$. The lower length of edible fruit $(3.26 \mathrm{~cm})$ was recorded with $\left(\mathrm{T}_{13}\right)-\mathrm{F}_{4} \mathrm{~S}_{0}$ (Fig. 1b). These results were in conformity with the findings of Yadav et al., (1989) in pointed gourd.

\section{Fruit diameter (cm)}

The interaction effect of $\mathrm{N}, \mathrm{P}, \mathrm{K}$ fertilizer levels and plant density recorded higher for fruit diameter with $\left(\mathrm{T}_{8}\right)-\mathrm{F}_{2} \mathrm{~S}_{3}(4.78 \mathrm{~cm})$, while the lower fruit diameter $(3.19 \mathrm{~cm})$ was recorded with $\left(\mathrm{T}_{13}\right)-\mathrm{F}_{4} \mathrm{~S}_{0}$. These results were in conformity with the findings of Choudhari and More (2002) in cucumber.
Fig.1b Length of edible fruit (cm)

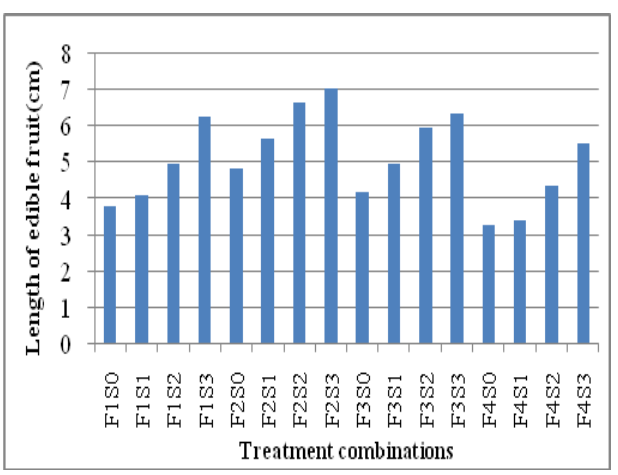

Effect of NPK fertilizers and plant densities on yield parameters of pointed gourd

\section{Yield per vine (kg)}

Effect of NPK levels, plant density and their interactions differed significantly for yield per vine. The higher yield per vine (6.9 $\mathrm{kg}$ vine-1) was recorded with $\left(\mathrm{T}_{8}\right)-\mathrm{F}_{2} \mathrm{~S}_{3}$ which was followed by $\left(\mathrm{T}_{7}\right)-\mathrm{F}_{2} \mathrm{~S}_{2} \quad(6.02 \mathrm{~kg}$ vine1).However the lowest yield per vine $(1.71 \mathrm{~kg}$ vine-1) was recorded with $\left(\mathrm{T}_{13}\right)-\mathrm{F}_{4} \mathrm{~S}_{0}$ (Table 5). These results indicated that the efficiency of nitrogen increased considerably by a simultaneous application of phosphorus and potassium. Improvement of vegetative growth and fruiting could be due to combined application of nitrogen, phosphorus and 
potassium. The fruit yield per plant in terms of number and total weight of fruits was more in medium spaced plants compared to narrow spaced plants could be due to more number of branches, leaf area, availability of nutrients, light, water and less competition from adjacent plants. These results were in conformity with the findings of Yadav et al., (1989), Dash and Tripathy (2001) in pointed gourd.

\section{Total Yield per hectare (t ha-1)}

It was revealed from Table 5 that the interaction effect due to NPK levels combinations and plant densities on total yield was found to be significant. Significantly maximum total yield $(31.25 \mathrm{t}$ ha-1) was obtained with the treatment combination of $\left(\mathrm{T}_{8}\right)-\mathrm{F}_{2} \mathrm{~S}_{3}$, whereas $\left(\mathrm{T}_{13}\right)-\mathrm{F}_{4} \mathrm{~S}_{0}$ gave the minimum total yield $(6.87 \mathrm{t}$ ha- 1$)$. At medium plant density the performance of individual plants was improved with respect to yield components.

The total fruit yield per hectare was more due to availability of sufficient nutrients, light, water and less competition from adjacent plants. These results were in conformity with the findings of Singh et al., (2007) in pointed gourd.

In conclusion the results of present investigation indicated that application of 100 per cent recommended dose of NPK (F2) and medium plant density $\left(S_{3}\right)$ have maximum yield of pointed gourd. Among the treatment combinations of N,P,K levels and plant densities, the treatment combination $\mathrm{T}_{11}\left(\mathrm{~F}_{3} \mathrm{~S}_{2}\right.$ : $125 \% \mathrm{RDF}+$ low plant density $(1.5 \mathrm{~m} \times 1.5 \mathrm{~m})$ recorded maximum main vine length and number of branches per plant, however $\mathrm{T}_{8}$ $\left(\mathrm{F}_{2} \mathrm{~S}_{3}: 100 \% \mathrm{RDF}+\right.$ medium plant density $(1.5 \mathrm{~m} \times 1.0 \mathrm{~m}))$ recorded maximum number of nodes per vine and total fruit yield per hectare.

\section{References}

Anjanappa, M., Venkatesha, J and Suresh Kumara, B. 2012. Growth, yield and quality attributes of cucumber (cv. Hassan local) as influenced by integrated nutrient management grown under protected condition. Vegetable Science 39(1): 47-50.

Arshad, I., Wajiha., Ali,H and Ahmed Khan, Zaheer. 2014. Effect of different levels of npk fertilizers on the growth and yield of greenhouse cucumber (Cucumis sativus) by using drip irrigation technology. International Journal of Agricultural Research (IJAR).1(8):650-660.

Choudhari, S. M and More,T.A. 2002. Fertigation, fertilizer and spacing requirement of tropical gynoecious cucumber hybrids. Acta Horticulturae.233-240.

Das, M. K., Maity, T. K and Som, M. G.1987. Growth and yield of pointed gourd (Trichosanthes dioica Roxb.) as influenced by nitrogen and phosphorus fertilization. Vegetable Science. 14(1): $18-26$

Dash, S. K and Tripathy, L. 2001. Studies on different plant density models on growth and flowering of pointed gourd (Trichosanthes dioica Roxb.) South Indian Horticulture. 49: 55-57.

Hazra, P., Chattopadhyay, A., Karmakar and Dutta, S. 2011. Modern technology in vegetable production. New India publishing Agency. Pitam pura, New Delhi.pp.380-384.

Jan, M., Iqbal M., Ghafoor, N.D., Waseem, A., Jillani, K., M.S and Khan, D.I. 2000. Effect of NPK fertilizers and spacing on the yield of bottle gourd (Lagenaria siceratia $\mathrm{M}$ ). Pakistan journal of Biological Sciences 3(3): 448-449.

Rahman, A.H.M.M., M. Anisuzzaman, F. 
Ahmad, A.K.M.R. Islam, and A.T.M.N. Naderuzzaman. 2008. Studies on nutritive value and medicinal uses of cultivated cucurbits. J. Appl. Sci. Res. 4:555-558

Seshadri, V.S. 1990. Cucurbits. p. 91-154. In: T.K. Bose and M.G. Som (eds.), Vegetable crops in India. Naya Prokash, Kolkata, India.

Singh, K.P., Krishna Mohan,T and Haque, M. 2007.Studies on planting time, method and plant density on yield and yield attributing characters on pointed gourd (Trichosanthes dioica Roxb.) in Gangetic diara of Bihar. Asian journal of horticulture. 2(1): 47-49.

Sukhatme PV and Amble VN. 1995. Statistical methods for Agricultural workers, ICAR, New Delhi.

Yadav, J. P., K and Jaiswal, R. C. 1989. Influence of various spacings and methods of training on growth and yield of pointed gourd (Trichosanthes dioica Roxb.). Vegetable Science. 16(2):113118.

\section{How to cite this article:}

Sushree Choudhury and Debasis Sarangi. 2020. Interactive Effect of NPK Fertilizers and Plant Densities on Growth and Yield of Pointed Gourd (Trichosanthes dioica Roxb.). Int.J.Curr.Microbiol.App.Sci. 9(07): 2303-2311. doi: https://doi.org/10.20546/ijcmas.2020.907.268 